\title{
The Legumes: The Earliest Domesticated Plants in the Near East?
}

\section{Citation}

Kislev, M. E., and O. Bar-Yosef. 1988. "The Legumes: The Earliest Domesticated Plants in the Near East?" Current Anthropology 29 (1) (February): 175.

\section{Published Version}

doi:10.1086/203623

\section{Permanent link}

http://nrs.harvard.edu/urn-3:HUL.InstRepos:12211495

\section{Terms of Use}

This article was downloaded from Harvard University's DASH repository, and is made available under the terms and conditions applicable to Other Posted Material, as set forth at http:// nrs.harvard.edu/urn-3:HUL.InstRepos:dash.current.terms-of-use\#LAA

\section{Share Your Story}

The Harvard community has made this article openly available.

Please share how this access benefits you. Submit a story.

\section{Accessibility}




\section{The Legumes: The Earliest Domesticated Plants in the Near East? ${ }^{1}$}

\author{
M. E. KISLEV AND O. BAR-Y OSEF \\ Department of Life Sciences, Bar-Ilan University, \\ Ramat Gan $52 \mathrm{IOo} /$ Institute of Archaeology, Hebrew \\ University, Jerusalem 9I905, Israel. 6 III 87
}

The Near East was a major nuclear area in which agriculture was adopted as a survival strategy about I0,000 years ago. Archaeological and palaeobotanical studies over the last three decades have been aimed at testing the various models proposed to explain the emergence of farming societies. In particular, research has concentrated on clarifying the origins, genetic changes, and methods of planting and harvesting of cereals. This focus is not surprising, as wheat and barley breads have been staples throughout the region's recorded history. Pulses, although recognized as important, have received much less attention (but see Renfrew 1973, Zohary and Hopf I973, Ladizinsky and Adler I976, and Ladizinsky I979).

The widespread use of legumes throughout the Mediterranean basin at the dawn of agriculture is inferred from the distribution of their wild ancestors and the variety of regions in which they have been transformed into domesticated plants: pea (Pisum sativum) and horsebean (Vicia faba) in the Levant (Ben-Zeev and Zohary 1973, Kislev 1985), lentil (Lens culinaris) and chickpea (Cicer arietinum) in Anatolia (Ladizinsky I979, Ladizinsky and Adler 1976), chickling vetch (Lathyrus sativus) in the Balkan Peninsula, flat-podded vetchling (L. cicera) in southwestern Europe (Kislev n.d.), and such so-called less important legumes as $V$. narbonensis in the Near East (Scheibe 1934) and Lens nigricans in southern Europe (Ladizinsky and Braun I983). Because of their superior nutritional value, early ripening, and wide environmental distribution, pulses may perhaps have been cultivated earlier than cereals in the Near East and served as a model for the raising of additional crops.

Current views on the history of plant domestication rely on the scanty archaeobotanical evidence and the historical evolution of agricultural economies. On the basis of radiometric dates, most authorities agree that the domestication of cereals and pulses occurred during the 8 th and 7 th millennia b.c. (Renfrew 1969, Zohary and Hopf I973, van Zeist 1976, Hopf I983). Whereas wild and domesticated wheat and barley are readily distinguished morphologically this is not the case for

I. (C) I 988 by The Wenner-Gren Foundation for Anthropological Research. All rights reserved ooI I-3204/88/290I-0009\$I.00. We are grateful to J. D. Speth (Museum of Anthropology, University of Michigan, Ann Arbor), W. Wetterstrom, and the late G. Ll. Isaac (Peabody Museum, Harvard University) for many helpful comments on an earlier draft of this paper. We are fully responsible for any shortcomings of the present version. pulses. Therefore, when the latter are uncovered in archaeological deposits, it is difficult to determine whether they were cultivated or gathered. It is generally assumed that wild pulses and wild cereals, along with various other seeds, nuts, tubers, herbs, etc., formed the vegetal diet of Epi-Palaeolithic hunter-gatherers in the Levant, but because of the absence of plant remains in most sites of this period this assumption has not been verified. ${ }^{2}$ Ethnographic data indicate that prehistoric Mediterranean people, like other mid-latitude human groups, were predominantly gatherers of vegetal foodstuffs (Gaulin and Konner I977). We suggest that these hunter-gatherers' intimate knowledge of the vegetation enabled them, in a later period, to enter into new relationships involving the propagation and cultivation of selected species. The presence of grinding stones in the Levantine Upper Palaeolithic and pounding tools (mortars and pestles) in Epi-Palaeolithic sites (Bar-Yosef I980, I98I) testifies to the possible use of wild seeds as part of the vegetal diet. This contention is supported by measurements of $\mathrm{Sr} / \mathrm{Ca}$ ratios in skeletal remains from sites of these periods (Sillen I984). Such preadaptations were necessary for the evolution of subsistence strategies into the manipulation of the reproduction and growth of some plants that heralded what we generally call the "Agricultural Revolution."

Among the annuals of the eastern Mediterranean, it is the cereals and the pulses that produce the best edible seeds for humans. Other species, such as Chenopodium album, also yield seeds in the late spring and early summer, but these are often smaller and more difficult to process into food (Helbaek I960). Cereals and pulses differ in various respects, and these differences may have been crucial for the decision making of prehistoric gatherers.

Cereals grow in large natural stands that cover hundreds of hectares in the oak-pistachio belt of the Near East (Harlan and Zohary I963). Pulses are basically dispersed within the same Mediterranean shrubland but in smaller patches.

Cereals ripen and can be harvested from early May until the end of June, depending on topography and location. Pulses ripen in March-April, generally a month before the cereals (Gophna and Kislev I979, Plitmann and Kislev n.d.). Within the same patch not all the pods ripen at the same time, a trait enabling a second harvesting if the plants are not uprooted.

The collection of wild cereals has few requirements. Hand picking and a basket are sufficient. Plucking the

2. The absence of plant remains can be partially explained by the nature of fruit and seed processing and consumption. When eaten raw or ground into porridge, most fruits and seeds have little chance for preservation. Only when parched, roasted, or accidentally charred are they found in archaeological deposits. Moreover, Mediterranean soils provide poor conditions for preservation, as repeated subjection to wet winters followed by dry summers quickly destroys vegetal residues. In addition, the dearth of plant remains is partly the result of excavation methods that do not include the flotation or careful dry-sieving (using fine mesh) and hand picking that are essential for the recovery of botanical specimens. 
entire plant is not as easy as with pulses. Only when the straw is needed (e.g., as material for basketry) does the use of a sickle become essential. Examples of such use have recently been discovered in Nahal Hemar, a Pre-Pottery Neolithic site in the Judean Desert (BarYosef 1985). Domesticated cereals, with their nonbrittle rachises, are most effectively cut in bunches with a sickle. Pulses, whether wild or domesticated, can be gathered without this tool. Except for horsebean, they usually have no major stalk, and the branches either lean on each other or spread across the ground. Plucking the whole plant is therefore the most efficient way of retrieving the maximum number of pods. Needless to say, the best time for collection is before the pods dry and open. The patchy distribution of pulses makes a "feedas-you-go" strategy (Isaac I984) most efficient.

Separating the grains of wild cereals from their hard glumes requires roasting and perhaps pounding and sorting. The first domesticates, emmer and barley, have softer glumes and thinner awns than their ancestors (Zohary 1969). The naked grains of the fully domesticated species are more easily made into flour or porridge. Pulses may be consumed raw with no preparation; pods may be eaten green or opened for their seeds. In the halfgreen, half-yellow stage, before fully mature, pulsesespecially chickpea, horsebean, and garden pea-may be roasted and eaten. Bunches of half-roasted whole chickpea plants, called hamle malane in Arabic, are still consumed today (Avitsur 1968). Dried pulse seeds, however, demand more preparation, including hours of soaking in water or pounding followed by soaking and/or cooking.

In contrast to cereals, several species of pulses are toxic. While lentil, pea, and chickpea, the leading pulses in Old World agriculture, are not, horsebean is slightly toxic and cannot be eaten by individuals with hereditary glucose-6 phosphate dehydrogenase deficiency (Szeinberg, Sheba, and Adam 1958). In such individuals ingestion of the bean or inhalation of its pollen can cause favism, a hemolytic anemia expressed by pallor, fatigue, dyspnea, nausea, abdominal or back pain, fever, and chills. Favism may be fatal to children under six years of age (Mager, Chevion, and Glaser I980). The most dangerous modern pulses are two species of Lathyrus, chickling vetch and flat-podded vetchling. The former (L. sativus) is generally grown in countries, such as India, where failure of cereal crops is anticipated because of recurrent drought. Lathyrism, the disease caused by their consumption, is characterized by paralysis of the legs. It occurs when the pulse accounts for a third to half of the daily caloric intake for a period of three to six months and often attacks 20-30-year-old males. Today it is more common in rural India than in the circumMediterranean countries or East Africa (Padmanaban I980). To reduce the risk of favism or lathyrism, the seeds must be boiled and drained or soaked overnight and then dried; these procedures extract up to $80 \%$ of the toxins (Padmanaban I980).

The nutritional values of cereals and pulses are somewhat similar, except that protein content is greater and of better quality in the latter (tables I and 2). The caloric
TABLE I

Food Nutrients in Grams per Ioo g Edible Protein

\begin{tabular}{|c|c|c|c|c|}
\hline & Calories & Protein & Fat & Carbohydrate \\
\hline \multicolumn{5}{|l|}{ Nuts } \\
\hline Acorns & 270 & 4.8 & $5 . I$ & 53.9 \\
\hline Almonds & 610 & I 8.6 & 54.2 & 16.9 \\
\hline Pistachios & 594 & 20.0 & 54.0 & I 5.0 \\
\hline \multicolumn{5}{|l|}{ Pulses (dry) } \\
\hline Peas & 340 & 24.0 & 1.2 & 59.0 \\
\hline Lentils & 335 & 22.5 & I.O & 60.0 \\
\hline Chickpeas & 350 & 20.0 & 5.1 & 59.0 \\
\hline Horsebeans & 326 & 24.5 & I. 4 & 55.5 \\
\hline Chickling vetch & 345 & 27.4 & I.I & 59.8 \\
\hline \multicolumn{5}{|l|}{ Cereals } \\
\hline Wheat & 342 & I 2.0 & 2.2 & 71.0 \\
\hline Barley & 356 & 10.5 & 2.1 & 72.0 \\
\hline \multicolumn{5}{|l|}{ Meat } \\
\hline Goat & 157 & I 8.4 & 9.2 & 0 \\
\hline Lamb & 267 & 17.0 & 21.0 & 0 \\
\hline Mutton & 440 & 22.5 & 39.0 & 0 \\
\hline
\end{tabular}

SOURCES: Gopalan, Ramasastri, and Balasubramanian (I97I), Guggenheim (I976), Hassan (I976), and Harris (I98I).

values of pulses and cereals are in the same range, and carbohydrate values are similar. Although a full comparison between wild and domesticated forms is not available, lentils of both types exhibit basically the same values (G. Ladizinsky, personal communication). That protein quality is better in pulses than in cereals is due to the higher content of amino acids such as lysine (two to three times more), threonine, valine, and isoleucine (a quarter to half again as much). Pulses are therefore the closest vegetal replacement for meat protein.

For hunter-gatherers in Levantine environments, winter was the season of resource stress, a time not only of calorie shortage but also of difficulty in obtaining adequate fat and protein (Speth and Spielmann I 983). Fats, especially the essential fatty acids, linoleic and linolenic acids, could have been provided by wild olives (Gophna and Kislev 1979), pistachios, and the seeds of annuals such as Linum and Papaver. Pulses would have been a good source of protein.

To sum up, for hunter-gatherers, pulses had at least these advantages over wild cereals: they ripen in late winter/early spring, when meat shortage in the Levant might have been at its peak even if storage was practiced; they are easily collected and prepared; and, finally, their patchy distribution might have helped alleviate possible conflict over territory.

The exploitation of pulses is not uniquely a human strategy. A large number of insects, birds, rodents, and ruminants also consume them, and some even cache seeds for leaner periods (Smith and Reichman I984). By observing these animals, humans could have learned about storing pulses. Competition between humans and animals in gathering pulses might have depleted the patches more rapidly than would have happened with 
TABLE 2

Essential Amino-Acid Composition of Animal and Plant Foods in Grams per roo $g$ of Nitrogen

\begin{tabular}{|c|c|c|c|c|c|c|c|c|c|}
\hline Food & Histidine & Isoleucine & Leucine & Lysine & Methionine & Phenylalanine & Threonine & Tryptophan & Valine \\
\hline Beef & I I -28 & I $8-37$ & $4 I-62$ & $44-76$ & $12-20$ & $21-37$ & $23-35$ & $4-12$ & $3 I-44$ \\
\hline Lamb & I4 $4-2$ I & $26-39$ & $42-54$ & $4 I-59$ & $14-16$ & $23-31$ & $24-33$ & $6-10$ & $29-35$ \\
\hline Pork & I $4-29$ & $25-40$ & $44-54$ & $46-62$ & II $-2 I$ & $22-28$ & $22-34$ & $5-9$ & $30-36$ \\
\hline Rabbit & 14 & 32 & $48-49$ & $52-55$ & $16-17$ & $23-24$ & $30-31$ & - & $30-3 I$ \\
\hline Eggs & $9-23$ & $32-52$ & $49-6 I$ & $32-49$ & $9-29$ & $28-50$ & $24-46$ & $7-13$ & $4 I-55$ \\
\hline Wheat & $8-16$ & $19-30$ & $35-43$ & $13-22$ & $4-18$ & $23-36$ & I I-2I & $5-8$ & $22-30$ \\
\hline Barley & $8-15$ & $20-30$ & $34-44$ & $14-22$ & $6-13$ & $24-36$ & $14-25$ & $5-10$ & $24-33$ \\
\hline Chickpeas & I3-2I & $32-39$ & $42-50$ & $34-57$ & $5-13$ & $23-42$ & $17-30$ & $2-9$ & $25-39$ \\
\hline Lentils & I I-I 6 & $27-4 I$ & $34-53$ & $3 I-46$ & $2-10$ & $23-33$ & I $5-3$ I & $I-I 2$ & $30-40$ \\
\hline Peas & I $3-29$ & $29-45$ & $42-64$ & $40-55$ & $2-18$ & $23-40$ & I $8-31$ & $2-12$ & $26-49$ \\
\hline
\end{tabular}

SOURCE: Altman and Dittmer (1968:9-56).

TABLE 3

Earliest Archaeological Records of Eastern Mediterranean Pulses

\begin{tabular}{|c|c|c|c|c|c|c|c|c|c|}
\hline Site & ${ }^{14} \mathrm{C}$ Date в.c. & Viciae & Cicer & Lathyrus & Lens & Pisum & $\begin{array}{c}\text { Vicia } \\
\text { ervilia }\end{array}$ & $\begin{array}{l}\text { Vicia } \\
\text { faba }\end{array}$ & Source \\
\hline Kebara & (Mousterian) & * & - & - & * & - & * & - & \\
\hline Hayonim Cave & I0,400-10,000 & a & - & - & - & - & - & - & Hopf and Bar-Yosef (n.d.) \\
\hline Franchthi & II,000-7000 & * & - & - & * & - & - & - & Hansen and Renfrew (I978) \\
\hline $\begin{array}{l}\text { Abu Hureyra } \\
\text { (Mesolithic) }\end{array}$ & $9000-8500$ & * & - & - & * & - & * & I & Hillman (1975) \\
\hline Salibiya IX & (Khiamian) & * & - & - & - & - & - & - & Kislev, personal observation \\
\hline Jericho (PPNA) & $8300-7300$ & - & - & - & 2 & - & - & - & Hopf (1983) \\
\hline Mureybit & $8050-7550$ & * & - & - & 20 & - & 5 & - & $\begin{array}{l}\text { van Zeist (I970), van Zeist and } \\
\text { Casparie (I968) }\end{array}$ \\
\hline Aswad I & $7800-7300$ & 50 & - & - & 6 & 39 & I & - & $\begin{array}{l}\text { van Zeist and Bakker-Heeres } \\
\text { (1979, 1985) }\end{array}$ \\
\hline Çayönüu I & $7500-7200$ & I79 & $\mathbf{I}$ & - & - & 45 & 67 & - & van Zeist (I972) \\
\hline $\begin{array}{l}\text { Abu Hureyra } \\
\text { (Neolithic) }\end{array}$ & $7500-6500$ & $\star$ & 12 & - & * & - & - & - & Hillman (I975) \\
\hline Jericho (PPNB) & $7300-6500$ & - & 2 & - & 640 & 344 & - & 30 & Hopf (I983) \\
\hline Çayönü 2-5 & $7200-6500$ & 267 & 3 & $\mathbf{I}$ & 162 & II 4 & I4I & - & van Zeist (I972) \\
\hline Beidha & $7000-6600$ & 3,200 & - & - & 553 & * & - & - & Helbaek (I966) \\
\hline Hacilar (Aceramic) & 6750 & - & - & - & 3 & - & - & - & Helbaek (I 970) \\
\hline Aswad II & $7000-6500$ & 172 & - & - & $2 I$ & 36 & - & - & van Zeist and Bakker-Heeres (I985) \\
\hline Ghoraifé I & $6800-6300$ & 24 & 3 & $\mathbf{I}$ & 3 & 19 & I & - & van Zeist and Bakker-Heeres (I985) \\
\hline $\begin{array}{l}\text { Franchthi } \\
\text { (Mesolithic) }\end{array}$ & $7300-6000$ & * & - & - & * & $\star^{\prime \prime}$ & - & - & Hansen and Renfrew (1978) \\
\hline Yiftah'el & 6500 & - & - & - & $(7.4 \mathrm{~kg})$ & - & - & 2,750 & van Zeist and Bakker-Heeres (I985) \\
\hline $\begin{array}{l}\text { Ali Kosh (AK } \\
\text { phase) }\end{array}$ & $6450-6$ I 50 & - & - & - & I & - & - & - & Helbaek (I 969) \\
\hline Ghoraifé II & $6400-6100$ & - & 32 & - & - & 7 & - & - & van Zeist and Bakker-Heeres (I985) \\
\hline Jarmo & $6500-6000$ & - & - & * & * & $\star^{\prime}$ & - & - & Helbaek (I959) \\
\hline Can Hasan III & $6500-6000$ & 45 & - & - & 15 & - & 37 & - & Hillman (r972) \\
\hline Ain Ghazal & $6600-6000$ & - & * & - & * & * & - & * & Rollefson (I985) \\
\hline Ramad I & $6350-6050$ & II & - & - & 75 & 25 & 2 & - & van Zeist and Bakker-Heeres (I985) \\
\hline Knossos & 6100 & - & - & - & 210 & - & - & - & Evan (I968) \\
\hline Cape Andreas & 6000 & $2 I$ & - & - & 147 & 4 & - & I & van Zeist (I98I) \\
\hline Prodromos & 6000 & - & - & 200 & I3 & $28 I$ & - & - & Halstead and Jones (I980) \\
\hline Ramad II & $6100-5800$ & I4I & 20 & - & 558 & $\mathrm{I} 43$ & - & - & van Zeist and Bakker-Heeres (1985) \\
\hline
\end{tabular}

NOTE: The numbers are of seeds found, including those of related species.

$\star$, Present but not counted.

a 6 Lupinus. 
stands of wild cereals, and pressure on these patchy resources might have led to experimentation in sowing pulses. This step would have required no special preparation and could have occurred on and off before the intentional cultivation of cereals. Perhaps we should add this activity to the list of preadaptations that preceded the establishment of full-fledged Levantine farming communities. Moreover, the patchy distribution of pulses might help to explain the settlement pattern recorded for the Epi-Palaeolithic (Bar-Yosef I980, I98I). Winter and early spring, the harshest seasons in Levantine environments, might have encouraged fission of huntergatherer groups that was partially justified by the patchy distribution of the available resources.

The archaeological record is not detailed enough to test this hypothesis (table 3; see also Plitmann and Kislev n.d.). Several indications make it seem worthwhile, however, to consider the possibility that pulses played a more important role in human diet during the Palaeolithic than has been envisaged. Pulses have been found in the Mousterian layers of Kebara Cave, in Early Natufian layers at Hayonim Cave (Hopf and Bar-Yosef n.d.), in the Late Natufian of Abu Hureyra, at the Khiamian site of Salibiya IX (ca. I0,500 b.p.) in the Lower Jordan Valley (Kislev, personal observation), and in every excavated early Neolithic site (10,300-8,000 b.p.). In several farming communities, such as Ali Kosh (Bus Mordeh phase, ca. 9,000 b.p.), Yiftah'el $(8,700-8,500$ b.p.), and Ain Ghazal (8,600-8,00o b.p.), pulses were the primary vegetal staple. The presence of pulses among the charred plant remains retrieved from archaeological sites seems to predate that of wild cereals. Their nutritional value, timing of availability, and accessibility would have made them ideal candidates for gathering and later for cultivation by the latest Levantine huntergatherers or earliest farmers.

\section{References Cited}

ALTMAN, P. L., AND D. S. DitTMER. I968. Metabolism. Bethesda, Md.: Federation of American Societies for Experimental Biology.

AVITSUR, S. I968. Forerunners of bread (in Hebrew). Tel Aviv.

BAR-y Os f, O. I980. Prehistory of the Levant. Annual Review of Anthropology 9:IOI-33.

- I98I. "The Epi-Palaeolithic complexes in the Southern Levant," in Préhistoire du Levant. Edited by J. Cauvin and P. Sanlaville, pp. 389-408. Paris: Editions C.N.R.S.

- I985. A cave in the desert: Nahal Hemar. Israel Museum, Jerusalem, Catalogue 258.

BEN-ZEEV, N., AND D. ZOHARY. I973. Species relationships in the genus Pisum L. Israel Journal of Botany 22:73-9I.

EVANS, J. D. I968. Knossos Neolithic. 2. Annual of the British School at Athens 63:239-76.

GAULIN, S. J. C., AND M. KONNER. I977. "On the natural diet of primates, including humans," in Nutri- tion and brain, vol. I. Edited by R. J. Wurtman and J. J. Wurtman, pp. I-86. New York: Raven Press.

GOPALAN, C., B. V. RAMASASTRI, S. C. BALASUBRAMANIAN. I97 I. Proximate principles, minerals, and vitamins: Nutritive values of Indian foods. New Delhi: Indian Council for Medical Research.

GOPHNA, R., AND M. E. KISLEV. I979.'Tel Ṣaf (I977I978). Revue Biblique 86: I I 2-I4.

GUGGENHEIM, Y. K. I976. Human nutrition (in Hebrew). Jerusalem: Magness Press.

HALSTEAD, P., AND G. JONES. I980. Early Neolithic economy in Thessaly: Some evidence from excavations at Prodromos. Anthropologika I:93-I I7.

HANSEN, Y., AND J. M. RENFREW. I978. PalaeolithicNeolithic seed remains at Franchthi Cave, Greece. Nature 271:349-52.

HARLAN, J. R., AND D. ZOHARY. I 966. Distribution of wild wheats and barley. Science I 53:1074-80.

HARRIS, D. R. I98I. "The prehistory of human subsistence: A speculative outline," in Food, nutrition, and evolution. Edited by D. N. Walcher and N. Kietchmer, pp. I 5-35. New York: Masson.

HASSA N, F. A. I976. "Diet, nutrition, and agricultural origins in the Near East," in Origine de l'élevage et de la domestication. Edited by E. Higgs, pp. 227-47. Preprints, UISPP Congress, Nice.

HELBAEK, H. I959. Domestication of food plants in the Old World. Science I 30:365-72.

r 960 . Comment on Chenopodium album as a food plant in prehistory. Bericht über das Geobotanische Forschungsinstitut Rübel in Zürich 31:16-19. I 966. Pre-Pottery Neolithic farming at Beidha: A preliminary report. Palestine Exploration Quarterly 98:6I-66.

. I969. "Plant collecting, dry farming, and irrigation agriculture in prehistoric Deh Luran," in Prehistory and human ecology of the Deh Luran Plain. Edited by F. Hole, K. V. Flannery, and A. J. Neely, pp. 383-426. Ann Arbor: University of Michigan Press.

. I970. "The plant husbandry of Hacilar: A study of cultivation and domestication," in Excavations at Hacilar, vol. I. Edited by J. Mellaart, pp. 189-244. Edinburgh: Edinburgh University Press.

HILLMAN, G. C. I972. "Plant remains," in Papers in economic prehistory. Edited by E. Higgs, pp. I 82-88. Cambridge: Cambridge University Press.

- I975. The plant remains from Tell Abu Hureyra: A preliminary report. Proceedings of the Prehistoric Society 4I:70-73.

HOPF, M. I983. "Jericho plant remains," in Excavations at Jericho, vol. 5. Edited by K. M. Kenyon and T. A. Holland, pp. 576-62 I. London: British School of Archaeology in Jerusalem.

HOPF, M., AND O. BAR-YOSEF.n.d. Plant remains from Hayonim Cave, western Galilee. Paléorient. In press.

IS A A C, G. LL. I984. "The archaeology of human origins: Studies of the lower Pleistocene in East Africa I97I-I98I," in Advances in world archaeology, vol. 3. Edited by F. Wendorf and A. E. Close, pp. I-87. New York: Academic Press. 
KISLEV, M. E. I985. Early Neolithic horsebean from Yiftah'el, Israel. Science 2 28:3 I9-20.

- n.d. Origins of the cultivation of Lathyrus sativus and $L$. cicera. MS.

LADIZINSKY, G. I979. The origin of lentil and its wild genepool. Euphytica 28: I79-87.

LADIZINSKY, G., AND A. ADLER. 1976. The origin of chickpea Cicer arietinum L. Euphytica 25:2 I I-I 7.

LADIZINSKY, G., AND D. BRAUN. I983. Evidence for domestication of Lens nigricans ( $M$. Bieb.) Godron in S. Europe. Botanical Journal of the Linnaean Society 87:169-76.

MAGER, J., M. CHEVION, AND G. GLASER. I980. "Favism," in Toxic constituents of plant foodstuffs, $2 \mathrm{~d}$ edition. Edited by I. E. Liener, pp. 265-94. New York and London: Academic Press.

PADMANABAN, G. I980. "Lathyrogens," in Toxic constituents of plant foodstuffs, 2 d edition. Edited by I. E. Liener, pp. 239-63. New York: Academic Press.

PLITMANN, V., AND M. E. KISLEV. n.d. Biological changes of pulses induced by domestication. Annals of the Missouri Botanical Garden. In press.

RENFREW, J. M. I969. "The archaeological evidence for the domestication of plants: Methods and problems," in The domestication and exploitation of plants and animals. Edited by P. J. Ucko and G. M. Dimbleby, pp. I49-72. London: Duckworth.

I973. Palaeoethnobotany: The prehistoric food plants of the Near East and Europe. New York: Columbia University Press.

ROLLEFSON, G. O. I985. The I983 season at the Early Neolithic site of Ain Ghazal. National Geographic Research I:44-62.

SCHEIBE, A. I934. Über Vorkommen und Nutzungsweise der Wilderbse (Pisum elatius Stev.) und der "Wildbohne" (Vicia narbonensis var. intermedia Strobl) in Anatolien. Der Züchter 6:234-40.

SILLEN, A. I984. Dietary change in the Epi-Palaeolithic and Neolithic of the Levant: The $\mathrm{Sr} / \mathrm{Ca}$ evidence. Paléorient I0: I49-55.

SMITH, C. C., AND O. J. REICHMAN. I984. The evolution of food caching by birds and mammals. Annual Review of Ecology and Systematics I 5:329-5 I.

SPETH, J. D., AND K. A. SPIELMANN. I983. Energy source, protein metabolism, and hunter-gatherer subsistence strategies. Journal of Anthropological Archaeology 2:I-3I.

SZEINBERG, A., CH. SHEBA, AND A. ADAM. I958. Selective occurrence of glutathione instability in red blood corpuscles of the various Jewish tribes. Blood I 3: 1043-53.

VAN ZEIST, W. I970. The Oriental Institute excavations at Mureybit, Syria: Preliminary report on the I965 campaign. 3. The paleobotany. Journal of Near Eastern Studies 29:167-76.

I972. Palaeobotanical results of the I970 season at Çayönü, Turkey. Helinium I 2: I-I 9 .

I976. On macroscopic traces of food plants in southwestern Asia. Philosophical Transactions of the Royal Society of London B 275:27-4I.
I98 I. "Plant remains from Cape Andreas-Kastros (Cyprus)," in Un site néolithique précéramique en Chypre: Cap Andreas-Kastros. Edited by A. le Brun, pp. 95-IO0. Paris: Editions A.D.P.F.

VAN ZEIST, W., AND J. A. H. BAKKER-HEERES. I979. Some economic and ecological aspects of the plant husbandry of Tell Aswad. Paléorient 5:16I-69. I985. Archaeobotanical studies in the Levant. I. Neolithic sites in the Damascus basin: Aswad, Ghoraifé, Ramad. Palaeohistoria 24:165-256.

VAN ZEIST, W., AND S. BOTTEMA. I966. Palaeobotanical investigations at Ramad. Annales Archéologiques Arabes Syriennes I6:179-80.

VAN ZEIST, W., AND W. A. CASPARIE. I968. Wild einkorn wheat and barley from Tell Mureybit in northern Syria. Acta Botanica Neerlandica I7:44-53.

ZOHARY, D. I969. "The progenitors of wheat and barley in relation to domestication and agricultural dispersal in the Old World," in The domestication and exploitation of plants and animals. Edited by P. J. Ucko and G. W. Dimbleby, pp. 47-66. London: Duckworth.

ZOHARY, D., AND M. HOPF. I973. Domestication of pulses in the Old World. Science I 82:887-94.

\section{The Development of an Early Iron Age Prehistory in Gabon ${ }^{1}$}

\author{
LAZARE DIGOMBE, P. R. SCHMIDT, \\ VINCENT MOULEINGUI-BOUKOSSO, \\ JEAN-BERNARD MOMBO, AND MICHEL LOCKO \\ Scientific Research Programme on Archaeology \\ (Digombe), Department of Geography \\ (Mouleingui-Boukosso, Mombo), Department of \\ History and Archaeology (Locko), Omar Bongo \\ University, Libreville, Gabon/Department of \\ Anthropology, Brown University, Providence, R.I. \\ 029I 2, U.S.A. (Schmidt). I 6 II 87
}

The set of radiocarbon dates recently reported from the South-eastern region of Gabon's Upper Ogooué Province (Digombe, Schmidt, et al. I985), of great consequence for the study of the African Iron Age and African history (see Digombe, Schmidt, et al. I984), has been enriched by ten more dates from Moanda in Upper Ogooué Province and three Early Iron Age dates from Lac Bleu near Mouila, the capital of Ngounie Province (Schmidt, Digombe, et al. I985) (fig. I). The Lac Bleu and Mouanda dates (including one of those previously reported) are particularly important because they are directly associated with Early Iron Age smelting. These dates and the industrial evidence associated with them constitute the

I. (c) 1988 by The Wenner-Gren Foundation for Anthropological Research. All rights reserved o0I I-3204/88/290I-0008 \$I.00. 